\title{
Determinants of Market Orientation Adoption among Small and Medium Enterprises (SMES) in South Africa
}

\author{
Job Dubihlela \\ Vaal University of Technology \\ Faculty of Management Sciences \\ 11 Dick King Street, SE 6 \\ Vanderbij/park 1911, South Africa \\ Tel: 27839855136 (w) 27169325392 (h) \\ e-mail: job@vut.ac.za
}

\section{Doi:10.5901/mjss.2013.v4n6p55}

\begin{abstract}
Purpose: The purpose of the study is to examine the determinants and barriers of market orientation by SMEs in South Africa. Methodology: Data was collected using the personal face-to-face interviews with the use of a structured questionnaire. A total of 350 SMES were selected randomly and visited within the various municipal areas in Vaal Triangle. These were obtained from Gauteng Enterprise Propeller (GEP) and Small Enterprise Development Agency (SEDA). Seventy-seven SMEs refused to participate resulting in 273 usable questionnaires. Exploratory factor analysis was used to identify the dimensions using the principal component analysis. Findings: A four-factor structure accounting for over $62,14 \%$ of total variance was established and discussed. The reliability analysis, reflected coefficient values ranging from 0.743 to 0.893 indicating satisfactory internal consistency amongst variables within each dimension. Implications: By analysing the determinants the adoption of market orientation among SMEs, managers and marketers are presented with recommended strategies and implications on how to manipulate market orientation for effective business performance. Marketing capacities of SMEs may be strengthened through implementing market orientation. Originality: SMEs are vital for socio-economic progress for developing economies. Effective implementation of market orientation can assist SMEs' growth and development.
\end{abstract}

Keywords: Market orientation, SMEs, Exploratory factor analysis, South Africa.

\section{Introduction}

Various authors, research institutions, professionals and researchers have come to the conclusion that small and medium sized enterprises (SMES) contribute significantly to economic development (Storey, 1994; Tsukahara, 2006; Singh \& Garg, 2008), to production, competitiveness, employment, industrial growth, organisational decentralization and social coherence (Barry \& Milner, 2002). SMES function as the source of new enterprises, new innovative products, dynamic applications and flexible business forms (Tambunan, 2011). In the process, they help meet the socio-economic needs; and form the zoning plans for the distribution of employment and income within the economy (Singh \& Garg, 2008). SMES add to the variety of goods and services offerings for customers to choose from, some of which may otherwise not be provided by the large businesses (Jackson, 2004). Overally, SMEs act as a catalyst for economic growth as well as the development of diverse industries such as the arts, human resources, education and sport (Cronje, Du Toit \& Motlatla, 2004).

The adoption of market orientation (MO) has the potential to positively impact SMES' business performance (BP). According to Vieira (2010), market orientation adoption is an indication of the extent to which a company implements its marketing strategy; facilitating its ability to anticipate, react to and capitalize on environmental changes that lead to superior business performance. In reviewing literature on the relationship between market orientation and business performance, various studies concurred with Chakravarthy (1986) who established that there was a positive relationship linking market orientation to increased business performance. market orientation has attracted professional and scholarly interests as a driver of business performance (Walsh \& Lipinski, 2009). Roomi, Harrison and Beaumont-Kerridge (2009) posit that the adoption of market orientation by SMEs enables them to enhance their ability to increase their business performance. If market orientation positively impacts business performance of SMES, then a study identifying the determinants of market orientation adoption is vital in a South African setting. In that vein, brief review of the importance 
of SMES provides a good pedestal for this study. They provide personalised services and make a positive contribution to wealth creation in the South African economy (DTI, 2005). They are breeding grounds for entrepreneurial talent and a testing ground for new products, and agents of change, widely facilitating innovation and competition within various national economies (Barry \& Milner, 2002).

\section{Literature Review}

This section provides a review of literature on the importance and contribution of SMEs to various facets of the economy, showing how that research on SMEs has practical implications.

\subsection{SMEs Sector Contribution to the Economic Development}

The SME sector contributes to key economic aggregates such as employment, Gross Domestic Product (GDP), innovation, exports and others. There are different views among scholars and policy makers about the dynamic contribution of SMEs. According to Tambunan (2011), Audretsch (2009) and Tsukahara (2006), SMEs make a significant contribution to reduction of poverty by providing employment opportunities. Kurokawa et al. (2010) posit that if the challenges confronting SMEs are addressed, they have a huge potential to become key players in generating productivity and competitiveness of the national production systems. Similarly, Subrahmanya et al. (2010) view SMEs as crucial in upgrading skills of owners, managers and their employees, strengthening linkages in the economically diverse activities, transferring technology know-how and complimenting large and multinational corporations in enabling sustainable development. SMEs are flexible and often act as subcontractors to large enterprises, ultimately leading to equitable distribution of income within the economy (Lloyd, 2002).

Empirical studies have shown that a large percentage of the growth in GDP and of the reduction in unemployment rates is because of the activities of the SMEs. Mahemba and Bruijn (2003) cite the fact that SMEs make up more than $90 \%$ of all business establishments worldwide. In the Republic of South Africa, it is estimated that $91 \%$ of the formal business entities are SMEs. The SMEs establishments contribute over $80 \%$ to global economies as compared to $63.6 \%$ contribution from their larger counterparts (Cronje et al., 2004).

The growth pattern and the overall health of the economy depend largely on dynamic business activities of both large enterprises and SMEs (Saayman, 1997). Vosloo (1994:53) summarised the importance of small enterprises as follows: "People make things happen, enterprises begin with people, enterprising people give rise to production, which in turn gives rise to employment". This statement means that without the spirit of enterprise as expressed in SMEs activity, there can be no employment creation or economic growth to talk about. At the bak of this reality, the government has targeted the SMEs sector in trying to alleviate the socio-economic challenges and prop economic growth (Subrahmanya et al., 2010), wealth distribution, crime reduction and unemployment (Mantle et al., 1992). Seven principal benefits of SMEs were identified and enlisted by Mantle et al. (1992)

- The SME is more labour -absorptive than other sectors,

- The cost of creating a job is lower with the SMEs than with the large enterprise,

- SMEs allow for more competitive markets,

- SMEs can adapt more rapidly and often use local recycled resources,

- They create employment for all previously disadvantaged persons; the youths and the women,

- Fewer skills are required in some cases, and

- They play a vital role in technical advancement and other innovations.

SMEs do not only just supply goods and services, but they are also consumers of the same (Ishengoma \& Kappel, 2008). This means that SMEs have an important role to play, positioning themselves in a marketplace by creating purchasing power and value chain capacity. They stimulate demand for both industrial and consumer goods adding to the activity of supplier organisations for various other sectors (Karungu et al., 2000). Mahadea and Rawat (2008) argue that SMEs create demand to the suppliers of industrial goods and are potential suppliers for new products arising from upgraded equipment. Essentially, the additional income-generation potential of SMEs "stimulates the demand for both consumption and capital goods within the economy" (Altenburg \& Von Drachenfels, 2006).

The current economic situation in South Africa iluminates the challenges where labour force is "released," not so much from the agricultural sector, but rather from large enterprises in the secondary and tertiary sectors (Dockel \& Ligthelm, 2005). Generally, large corporates although they still focus on growth and revenue generation, they are 
transforming themselves in such a way that "their demand for unskilled labour is decreasing" (Hallberg, 2000:71). This results in an abundant pool of unskilled labour, which SMEs can possibly employ and upgrade (Barry \& Milner, 2002).

\subsection{Determinants of Market Orientation Adoption}

Numerous studies have argued that market orientation is a key driver of business performance and various research efforts continue to focus on the relationship between the degree of market orientation and business performance (Narver \& Slater, 1990; Osuagwu, 2006; Kumar, 2009; Edigheji, 2010; Zebal \& Goodwin, 2012). Determinants and enablers of market orientation are those factors that influence the development of specific attitudes and practices that encompass the market orientation construct (Zebal \& Goodwin, 2012). Market orientation employs superior marketing processes that can provide an organisation with positional advantages; for as long as the competitors employ less efficient processes (Kim \& Mauborgne, 2009). In the long run, it is important that the organisation builds a dynamic market capability, one that enables and empowers the organisational stakeholders to adapt to change (Pelham, 2000). Such a capability provides an organisation with the means for adapting the marketing processes to changes in an environment, such as the changes in customer demands, the emergence of new markets and channels, or competitive moves (Kumar et al., 2011). In other words, the determinants and enablers are the fundamental elements generating a favourable environment for adopting and implementing a market orientation.

Market orientation often leads to positive effects on customer satisfaction and customer loyalty, resulting in better organizational performance (Lamb et al., 2010). An organization that is market-orientated enhances employee satisfaction and cooperation (Gatignon \& Xuereb, 1997). The characteristics of market orientation indicate a strong customer focus and an understanding of the organisational strengths and weaknesses (Kotler \& Armstrong, 2011). It also requires a solid understanding of the competition for an organization to be market oriented (Shapiro, 1988). Dobni and Luffman (2000) submit that a market orientation provides a context to facilitate the implementation of the marketing concept. Deng and Dart (1994) state that "market orientation is the implementation of a marketing philosophy, such that the level of market orientation would depend on the degree of implementation of the marketing concept". Perreault et al. (2011) also supports that view, submitting that market orientation is the more recent term for implementing the marketing concept by focusing on consumer needs and organisation's profit.

Organisations must build dynamic marketing capabilities that enable them to adapt, change, and renew operational approaches over time (Homburg \& Pflesser, 2000). Capabilities that provide the means for adapting the operational processes to changes in the marketing environment, such as changes in customer demands, the emergence of new markets and channels, and competitive changes (Sinkula et al., 1997). In fact, an organisation that wishes to become market oriented must state its mission as attaining a market orientation throughout its operations. This may include setting specific departmental guidelines that guide the flexibility of their departments' to achieve some market orientation (Lichtenthal \& Wilson, 1992). These operational procedures and guidelines, systems, activity frameworks, structures and processes as well as marketing and operational capabilities that can be adjusted to drive a market orientation culture are the determinants of market orientation (Kim \& Mauborgne, 2009). According to Gounaris and Avlonitis (1997) market orientation adoption requires organisational values embracing a philosophy, attitudes and behaviours that are conducive and enabling for market oriented strategies. As organisations increasingly recognise the strategic importance of becoming more market oriented, they of necessity, focus on the importance of driving market orientation deep into their organisational cultures (Kumar, 2009). Osuagwu (2006) posits that translating market orientation into action is traceable to marketing know-how, skills and organisational operational systems, coupled with competitive business environments.

\section{Problem Statement}

Despite an avalanche of theoretical contributions made by many scholars on market orientation literature, it appears that most SMEs in South Africa do not embrace market orientation as key for their marketing strategies and their performance. While there is considerable optimism that SMEs form one of the leading driving forces for economic expansion in post-apartheid South Africa, market orientation is admittedly the characteristic of a limited number of them. The majority of SMEs fail to develop and exploit the benefits of the market orientation concept. There is a difficulty associated with translating market orientation into action, traceable to lack of requisite marketing know-how, skills and systems. 
Although there are scholarly arguments pertaining to the application of marketing philosophy in developing economies including South Africa, there remain several moral risks affecting the performance of SMEs. One of the notable challenges is their lack of market orientation, especially for small to medium businesses where the owner/manager plays a crucial decision-making role (Fafchamps, 1992). Although research on market orientation is abundant, most of the past studies mainly focused on manufacturing sectors(Bhuian, 1998; Zebal \& Goodwin,2012), and very few researchers have addressed, in the empirical sense, the proposition that the adoption of market orientation leads to improved business performance (Kumar et al, 2011)for SMEs, especially in developing economies such as South African. To fill this existing gap in literature, the present study attempts to examine the current state of market orientation for SMEs in South Africa.

\section{Purpose of the Study}

The paper seeks to advance the findings advocated in previous studies on market orientation. It employs a factor analytical approach to identify the determinants of market orientation and analyse the adoption of market orientation among SMEs in South Africa.

\section{Methodology}

To obtain an impartial perspective, a literature review was conducted on the determinants of market orientation adoption as well as an empirical enquiry. Primary data were collected using a quantitative research procedure with the use of a structured questionnaire as the survey instrument. The rationale for selecting a quantitative study was that it is cheaper, flexible and allows for replication of the research procedure thus enhancing validity and reliability of research findings. Quantitative studies possess the objectivity and coherence that is necessary for addressing the issues and difficulties (Malhotra, 2010) that underpin the non-adoption of market orientation by SMEs in South Africa.

\subsection{Population and the sample}

The historical evidence approach was used to determine the sample size for this research (Zikmund, 2000). The sample size of 350 was chosen, consistent with that used by a number of researchers in the area of market orientation business performance relationship. Table 1 provides the basis for the selection of the sample size.

Table 1: Determining the sample size

\begin{tabular}{|l|llc|}
\hline Year & Authors & Scope of study & Sample size used \\
\hline 1990 & Narver \& Slater & Survey of Western corporations (commodity and non-commodity) & 140 \\
\hline 1996 & Jaworski \& Kohli & Interviews with various American companies (USA) & 222 \\
\hline 1998 & Van Egeren \& O'Connor & Survey of managers from American service companies (USA) & 289 \\
\hline 1998 & Advani\&Borins & Survey of airports worldwide & 201 \\
\hline 1998 & Han, Kim \&Srivastava & Survey of American banks (financial services) & 134 \\
\hline 1998 & Morgan \& Strong & Survey of various UK companies & 149 \\
\hline 2001 & Harris & Survey of UK retail companies & 107 \\
\hline 2004 & Kaynak \& Kara & Survey of Chinese companies (various companies) & 179 \\
\hline 2005 & Lai \& Cheng & Survey of companies in Hong Kong (various industries) & 342 \\
\hline 2009 & Song \& Parry & Survey of US firms (diverse industries) & 308 \\
\hline
\end{tabular}

The sample constituted small and medium sized businesses in the Vaal Triangle. The target population was restricted to Managers, SME owners, Heads of Marketing Departments. An appropriate sampling frame was assembled from various lists that included a register from the Gauteng Enterprise Propeller (GEP), the Vaal Triangle business directory as well as SME databases from the relevant municipalities in the region. SMEs were randomly selected from the population so each population unit had an equally non-zero chance of being selected thus allowing statistical inferences to be made (Bradley, 2007). 


\subsection{Data Collection}

A cross-industry field survey of SMEs was carried out in Vaal Triangle through interviewing respondents using a predesigned data collection instrument (Malhotra, 2010). Five research fieldworkers were hired from a list of registered fourth year university students pursuing marketing degrees. The fieldworkers were briefly trained by the researcher for subject knowledge, interviewing skills, interpersonal skills and professionalism (Kanuk \& Berenson, 1975). Data collection activities took place in Vaal Triangle Region between 19 September and 31 October 2012; with many unanticipated challenges. The challenge started with the travelling costs when each of the ten fieldworkers had to commute from one company to another; agro-based SMEs would only be reached using researcher's vehicle as there were no taxis to the farms. There was also a problem in conducting interviews due to some other factors such as general public strikes called by the employees, and load-shedding (the manual close down of electricity by the supplier). In these cases, the respondents were unwilling to accommodate the fieldworkers.

In order to motivate the respondents to participate, they were informed that the findings would be useful for proSME government policies and small business initiatives. They were also given the option to name the place of their choice for the interviews for which most respondents preferred to be interviewed at their business premises. From the 350 companies approached to participate in the survey, due to a variety reasons (such as refusal, non-contacts, unsatisfactory questionnaires, delayed questionnaires), a total number of 273 usable questionnaires (39.3\%) were available for the data analysis.

\section{Findings and Discussion}

The results are explained taking into account the composition of the sample in terms of small and medium enterprises, the demographic analysis of the data and the descriptive statistics explaining the variables relating to the determinants of market orientation adoption. Thereafter, the exploratory factor analytical procedure and extraction of factors is discussed.

\subsection{Characteristics of the surveyed SMEs}

Table 2 provides the profile of the surveyed SMEs in terms of their legal form (business type), their period in existence (age of business in years), their annual turnover (revenue), and employment levels (number of employees). In terms of legal business forms, the respondents' feedback indicated that most entities that were surveyed were formally registered business enterprises. The sample consisted mainly of private limited companies (Pty Ltd) $(38.8 \%, n=106)$, partnerships $(25.3 \%, n=69)$, close corporations (CCs) $(24.2 \%, n=66)$, public companies $(3.3 \%, n=9)$, sole traders $(6.6 \%, n=18)$, and co-operatives $(1.8 \%, n=5)$. Of these business operations, $38.1 \%(n=104)$ of them had been in existence for over 10 years, $20.1 \%(n=55)$ had been in operation for 7-10 years, 19.8\% $(n=54)$ had been in operation for 3-6 years, while the remainder, 22\% $(n=60)$ were emerging enterprises that had operated for less than 3 years

Table 2: Age and legal forms of the surveyed SMEs

\begin{tabular}{l|c|c|c|c|c}
\hline \hline $\begin{array}{c}\text { SME's Legal Form (business } \\
\text { type) }\end{array}$ & Freq & $\%$ & $\begin{array}{c}\text { SME's Business Age } \\
\text { (years) }\end{array}$ & Freq & $\%$ \\
\hline Sole trader (one-man business) & 18 & 6.6 & Less than 3 years & 60 & 22.0 \\
\hline Partnership & 69 & 25.3 & Between 3-6 years & 54 & 19.8 \\
\hline Close corporation & 66 & 24.2 & Between 7-10 years & 55 & 20.1 \\
\hline Co-operative & 5 & 1.8 & Over 10 years & 104 & 38.1 \\
\hline Private company (Pty) Ltd & 106 & 38.8 & & & \\
\hline Public Company (Ltd) & 9 & 3.3 & & & \\
\hline Total & $\mathbf{2 7 3}$ & 100 & Total & $\mathbf{2 7 3}$ & 100 \\
\hline
\end{tabular}

\subsection{Descriptive statistics}

With the exploratory nature of the study, the data were initially analysed using descriptive statistics. Table 3 reports on the annual turnover performance of the surveyed SMEs. These two aspects of SMEs are most critical evidence of the availability or unavailability of resources to implement the market orientation, showing sustainability and growth. The 
employment figures for this specific sample-profile (Table 3) indicate that the majority of the employers are those SME businesses that employ less than 50 employees per business entity; with 37\% of the surveyed SMEs in the category of 10-50 employees and $36.6 \%$ in the category, of 10 employees or less. Approximately a quarter $(13.6 \%+10.6 \%+2.2 \%=26.4 \%)$ of the participating SME employed more than 51 employees per business entity. These results are consistent with Appiah-Adu (1998) who asserts that SMEs are important, although recruiting less per entity, their potentialfor job creation is in numbers. The sample also indicated that $30 \%$ of the participants had between $6-10$ years of work experience, $25 \%$ had between 3-5 years of work experience, and 22 percent had between 11-20 years of work experience. The majority of the participating firms (59.7\%) generated annual turnover that was less than R4 million (41\% generated less than R2 million and 18.7\% generated between R2 million and R4 million). The rest of the surveyed SME businesses (40.3\%)generated annual turnover above R4 million per annum (i.e. 10.6\%, 8.1\%, 7.0\% and 14.7\%). It is clear that survey results indicatefewer business operations making huge revenues.

Table 3: Turnover and employment capacity

\begin{tabular}{l|c|c|l|c|c}
\hline \multicolumn{1}{c|}{$\begin{array}{c}\text { Annual turnover performance } \\
\text { (rands) }\end{array}$} & Freq & $\%$ & \multicolumn{1}{|c|}{$\begin{array}{c}\text { Number of employees } \\
\text { (fulltime) }\end{array}$} & Freq & $\%$ \\
\hline Less than R2 million & 112 & 41.0 & Less than 10 employees & 100 & 36.6 \\
\hline Between R2 million and R4 million & 51 & 18.7 & Between 10 - 50 employees & 101 & 37.0 \\
\hline Between R4 000 001 and R8 million & 29 & 10.6 & Between 51 - 100 employees & 37 & 13.6 \\
\hline Between R8 000 001 and R16 million & 22 & 8.1 & Between 101 - 200 employees & 29 & 10.6 \\
\hline R16 000 001 and R32 million & 19 & 7.0 & Above 200 employees & 6 & 2.2 \\
\hline Over R32 million & 40 & 14.7 & & & \\
\hline Total & $\mathbf{2 7 3}$ & $\mathbf{1 0 0}$ & Total & $\mathbf{2 7 3}$ & 100 \\
\hline
\end{tabular}

\subsection{Industry sector composition for surveyed SMEs}

The study also sought to ensure that companies operating in diverse industry settings were included in the sample. Industries were selected to cover both high and low technology environments, and companies identified using the GEP and the SEDA databases. The industries covered and their representations in the sample are illustrated in Figure 1. The graph shows wholesale and retail (32.2\%), manufacturing (9.5\%), mining (4.0\%), agriculture (6.2\%), construction $(10.3 \%)$, financial services $(9.9 \%)$, transport and communications $(7.3 \%)$, energy and water $(6.6 \%)$, motor repairs $(11.4 \%)$, and community services (2.6\%) as represented in the sample. Although the majority of the respondents were wholesale and retail enterprises, the sample generally contained significant proportions of diverse industries. A cursory glance of the results indicates that a large proportion of the SME industries in the Vaal Triangle region are in fact manufacturing, construction, wholesale and retail.

Figure 1: Respondents industry sector

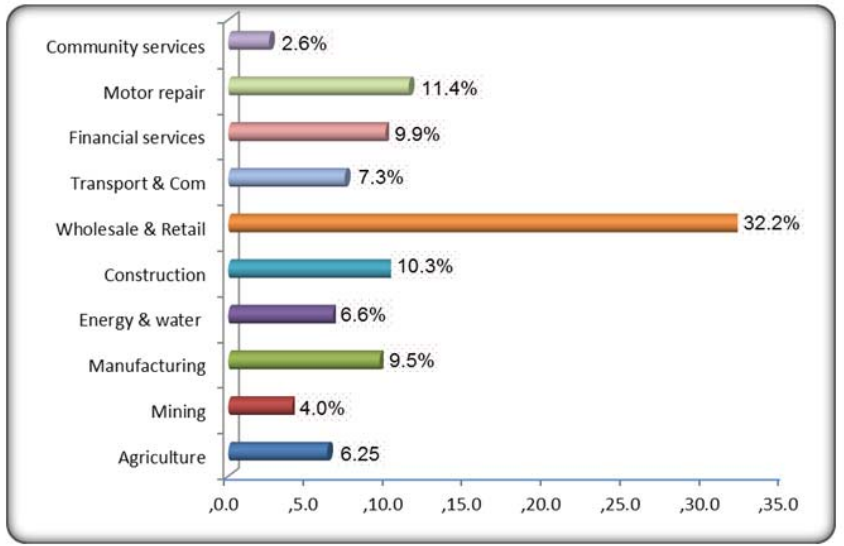




\subsection{Characteristics of the Informants}

The age structure of the sample as illustrated in Table 4 shows only $14.7 \%(n=40)$ of the respondents were under the age of 30 years, $25.6 \%(n=70)$ were aged between 30 and 39 years, $17.2 \%(n=47)$ represented the $50-59$ years age group, and a meagre $2.9 \%(n=8)$ of the sample were 60 years and above. The majority $39.6 \%(n=108)$ of the respondents were aged 40-49 years. It seems that the business leaders within the SMEs are concentrated within the age brackets of 30-59 years. This scenario is understandable since running a SME business is a challenging endeavour which requires experienced individuals who can make well-grounded marketing decisions (Parasuraman, 1998), especially strategic marketing decisions.

Table 4: Respondents age and level of education

\begin{tabular}{l|c|c|l|c|c}
\hline \hline \multicolumn{1}{c|}{ Age of respondent } & Freq & $\%$ & \multicolumn{1}{c|}{$\begin{array}{c}\text { Level of education } \\
\text { (respondent) }\end{array}$} & Freq & $\%$ \\
\hline Under 30 years & 40 & 14.7 & No formal education & 4 & 1.5 \\
\hline 30-39 years & 70 & 25.6 & Primary school education & 10 & 3.7 \\
\hline 40-49 years & 108 & 39.6 & High School education (Grade 12) & 55 & 20.1 \\
\hline $50-59$ years & 47 & 17.2 & Trade certificate & 91 & 33.3 \\
\hline 60 years and above & 8 & 2.9 & Undergraduate or equivalent degree & 79 & 28.9 \\
\hline & & Postgraduate & 34 & 12.5 \\
\hline Total & $\mathbf{2 7 3}$ & $\mathbf{1 0 0}$ & Total & $\mathbf{2 7 3}$ & 100 \\
\hline \hline
\end{tabular}

In terms of formal education levels, Table 4 shows that three quarters $(33.3 \%+28.9 \%+12.5 \%=74.7 \%)$ of the respondents had at least a tertiary qualification. This implies that the majority of the individuals who own or manage SME businesses either had a trade certificate (33.3\%), an equivalent of a degree (28.9) or a postgraduate qualification (12.5\%). The remainder $25.3 \%$ of the sample represented entrepreneurs either possessing basic education $(3.7 \%+20.1 \%=23.8 \%)$ or no formal education at all (1.5\%).

\section{Factor Analysis}

In addition to obtaining the sample descriptors and characteristics of the respondents a principal components factor analysis was conducted on the twelve-item scale to develop the set of factors that can be classified as determinants of the adoption of market orientation among SMEs in a South African setting. Prior to factor analysis the appropriateness of factorability on the data set was established. Examination of the correlation matrix (strength of linear association among variables) revealed that a substantial number $(74,9 \%)$ of the variables were $>0.30$ which according to Avkiran (1994) indicates factorability.

The Kaiser-Meyer-Olkin (KMO) and the Bartlett"s tests were also applied in order to further determine the appropriateness of the data set for factor analysis. The approximate chi-square was 4975,705 with 276 degrees of freedom and significant at $p<0.000$. The KMO value was 0.834 which is considered satisfactory (Malhotra, 2010). Both test statistics inferred that factor analysis was justifiable for the data set. The principal component analysis (initially unrotated) was applied, extracting factors with eigen values greater than one (Malhotra, 2010). This procedure extracted factors that were difficult to interpret. Factor analysis with Kaiser Normalisation (varimax rotation) was then applied in 9 iterations revealing a clearer factor structure with loadings ranging from 0.605 to 0.874 (only loadings of 0.60 were retained in the study). This is consistent with the guidelines of Uzoka et al. (2007) and Hair, Anderson, Tatham and Black (1992) who maintain that loadings of 0.30 are minimum levels; those around 0.40 are relatively important and those above 0.50 are considered more important.

This section provides a discussion of the factor analysis procedures, methods of factor extraction, factor structure; naming and interpretation of the dimensions.

\subsection{Methods used to extract factors}

The criterion for the factor extraction was determined using both the percentage of variance and the eigenvalues as 
illustrated in Table 5. The general rule is to retain all factors with eigenvalues greater than 1.0 whose total variance contribution is considered significant (Zikmund, 2000).

Table 5: Eigenvalues and variance explained

\begin{tabular}{|c|c|c|c|c|}
\hline \multirow{2}{*}{ Value } & \multicolumn{4}{|c|}{ Eigenvalues (determinants/enablers of market orientation) } \\
\cline { 2 - 5 } & Eigenvalue & \% Total Variance & Cumulative Eigenvalue & Cumulative \% \\
\hline 1 & 3.480 & 29.003 & 3.480 & 29.003 \\
\hline 2 & 1.634 & 13.613 & 5.114 & 42.615 \\
\hline 3 & 1.269 & 10.576 & 6.383 & 53.191 \\
\hline 4 & 1.074 & 8.951 & 7.457 & $62.142^{\star}$ \\
\hline Extraction Method: Principal Component Analysis & & & \\
\hline
\end{tabular}

The results illustrated in Table 5 show the factors and their eigenvalues, the percentages of variance and the cumulative percentage explained of $62.142 \%$. Both the percentage of variance explained and the eigenvalues indicate that four factors were appropriate to capture the essential dimensions of the determinants/enablers of market orientation construct.

\subsection{Dimensions of the determinants of market orientation}

Data was subjected to item reduction in order to achieve a clearer and simple factor structure (Malhotra, 2010). Item reduction was undertaken by examining low item correlations, multiple loadings and unstable variables; 11 items were dropped. The final 12-item factor structure of the determinants of market orientation is reported in Table 6.

Table 6: Rotated factor matrix and psychometric properties of the scale

\begin{tabular}{|c|c|c|c|c|}
\hline \multirow[b]{2}{*}{ Variables } & \multicolumn{4}{|c|}{ Number of factors } \\
\hline & 1 & 2 & 3 & 4 \\
\hline Employees get recognized for being sensitive to competitive moves & 0.784 & 0.026 & -0.023 & 0.107 \\
\hline We emphasize on experience rather than formal education & 0.722 & 0.019 & 0.200 & 0.087 \\
\hline $\begin{array}{l}\text { We hardly see any of our managers without having formal } \\
\text { marketing education. }\end{array}$ & 0.662 & 0.250 & -0.092 & 0.027 \\
\hline Customer satisfaction assessments influence senior managers pay & 0.605 & 0.295 & -0.029 & 0.228 \\
\hline $\begin{array}{l}\text { Top managers tell employees to be sensitive to competitor } \\
\text { activities }\end{array}$ & 0.085 & 0.832 & 0.038 & 0.142 \\
\hline $\begin{array}{l}\text { Top managers keep telling people to gear up for customers' future } \\
\text { needs }\end{array}$ & 0.242 & 0.755 & 0.114 & 0.121 \\
\hline In this company, survival depends on its adapting to market trends & 0.099 & 0.728 & 0.123 & 0.138 \\
\hline Top managers in this company like to take big financial risks & -0.005 & 0.056 & 0.874 & 0.094 \\
\hline $\begin{array}{l}\text { Managers believe higher financial risks are worth taking for higher } \\
\text { rewards }\end{array}$ & 0.032 & 0.172 & 0.861 & 0.013 \\
\hline There is ample opportunity for informal hall talk among individuals & -0.069 & 0.177 & 0.020 & 0.734 \\
\hline There is little or no interdepartmental conflict in this company & 0.272 & 0.014 & 0.252 & 0.684 \\
\hline $\begin{array}{l}\text { Departments feel the goals of their departments are in harmony } \\
\text { with each other }\end{array}$ & 0.256 & 0.212 & -0.082 & 0.670 \\
\hline Cronbach's Alpha & 0.803 & 0.743 & 0.772 & 0.763 \\
\hline Scale means & 13.9048 & 11.1465 & 7.0366 & 11.1648 \\
\hline Standard deviation & 3.4158 & 2.7494 & 2.0931 & 2.4053 \\
\hline
\end{tabular}


Items were considered markers of a component if their loading values were at least 0.45 . A 12-item market orientation determinants/enablers scale with four factors was finally extracted. In line with the theoretical dimensions espoused in the literature study, the four factors were meaningfully interpreted in terms of the conceptualised dimensions.

\section{Discussion of Results}

The discussion of the results are summarized from the descriptive analysis of the top four determinants to market orientation adoption by SMEs and the factor extraction procedure described under the results section. The findings are consistent with studies conducted by other researchers on the adoption patterns of the marketing concepts. Studies undertaken by Zebal and Goodwin (2004) for example, revealed that the determinants of adoption patterns in developing countries vary from those in developed nations. These dimensions discussed in this section were named after a careful examination of the characteristics of the variables under each dimension.

Factor one, named market-based reward systems (Variance=29.003\%; eigenvalue $=3.480$; mean=3.776) refers to organisational systems instrumental in shaping the behaviour of employees (Sigauw et al., 1994:106). The type of measurement and reward systems adopted by the organisation will determine the extent to which market orientation is adopted. Bulent and Seigyoung (2006:13) claimed that "a basic requirement for the development of a market-oriented firm is to create market-based measures of performance". In other words reliance on market-based factors for evaluating and rewarding managers may trigger overall market orientation of the organisation. Organisations that evaluate and administer rewards based on customer satisfaction and service levels are more likely to encourage the active generation and dissemination of market intelligence and responsiveness to market needs.

Factor two, top management emphasis (Variance $=13.613 \%$; eigen value $=1.634$; mean= 3.716), relates leadership approach to development of market orientation. A clear signal from top management regarding the importance of being responsive to customer needs is important for market-oriented organisations (Verhees \& Meulenberg, 2004). In addition to management's involvement, the necessity of communicating a commitment to market orientation is vital. Bulent and Seigyoung (2006) suggest that continuous reinforcement by senior management is required if individuals within the organisation are to be encouraged to generate, disseminate and respond to market intelligence. In line with Harris and Ogbonna (2001), this possibly means continuous management emphasis of market orientation may result in a greater overall market orientation.

Factor three was named inter-functional connectedness (Variance $=10.576 \%$, eigenvalue= 1.269 , mean= 3.597 ). It relates to a situation where the organisation has interdependent departments and functions, with existing conflict resolution mechanisms (Harris \& Ogbonna, 2001). Inter-functional connectedness facilitates the open flow of resources, work and assistance across all organisational departments (Ruekert \& Walker, 1987). Connectedness between departments also enables interaction and the exchange of information (Ruekert \& Walker, 1987). Deshpandé (1999:164) states that "connectedness enables adequate amounts of intelligence to be generated and also allows for its appropriate utilisation", and that increased interdepartmental connectedness may result in increased overall market orientation.

Factor four, management risk posture (variance= 8.951\%; eigenvalue= 1.074 ; mean= 3.722) relates to top management's risk seeking or risk averse tendencies. Jaworski and Kohli (2000) advise that senior management's willingness to take risks will encourage and facilitate organisation-wide commitment to innovation and responsiveness. On the other hand, a risk aversion policy adopted by senior management will tend to inhibit innovativeness and the creative processes of employees. Accordingly, Zebal and Goodwin (2012) views organisations whose management are high risk takers as more likely to be market oriented than those organisations whose management are risk averse.

\section{Concluding Remarks}

The findings of this preliminary study do provide basic support for a four dimensional structure highlighting the determinants of market orientation adoption among SMEs in the South Africa namely, market-based reward systems; top management emphasis; inter-functional connectedness and management risk posture. These findings are in line with other studies that suggest that the adoption of market orientation is multi-dimensional in its causality and that it largely depends on the business sector under investigation (Stansfield \& Grant, 2003; Osuagwu, 2006; Kohn \& Husig, 2006; Kumar, 2009). In this regard it may be concluded that a systematic implementation of market orientated strategies is positively related to overall business performance (Zebal \& Goodwin, 2012; Jaworski \& Kohli, 2000) and SMEs who fail to implement market orientation fail to reach their full marketing potential hence they put at risk the potential returns of their businesses. 
The SMEs operating in the South Africa economy are also threatened by a dynamic and highly unstable market conditions. Adoption and implementation of market oriented strategies is therefore needed in order to cushion SMEs from the challenging economic conditions, hostile competitive environment, and regressive operational environment.

\section{Limitations of the Study}

The study investigated SMEs operating within a developing economy (South Africa). There is a possibility that measures of market orientation adoption in developing nations may vary from those businesses operating in both advanced first world nations (developed countries) and underdeveloped poor economies. The study was not conducted country-wide. In order to refine the results, similar studies could be conducted in different provinces across South Africa. These limitations may indicate that caution is needed in the interpretation of these findings as these results may not be accepted as completely relevant in diverse settings. Also, it is important to note that while the four dimensions were identified and distinguished in this study as having the greatest impact on market orientation adoption, other dimensions may remain important in different environments.

\section{References}

Altenburg, T. \& Von Drachenfels, C. (2006). The 'new minimalist approach' to private- sector development: a critical assessment. Development Policy Review, 24(4):387-411.

Appiah-Adu, K. (1998). Market orientation and performance: Empirical tests in a transition economy. Journal of Strategic Marketing, 6:25-45.

Audretsch, D. (2009). Entrepreneurship, growth, and public policy. Cambridge: University Press.

Barry H \& Milner B. (2002). SMES and E-Commerce; a departure from the traditional prioritisation of training? Journal of European Industrial Training, 26(7):316-326.

Bhuian, S. N. (1998). An empirical examination of market orientation in Saudi Arabian manufacturing companies. Journal of Business Research, 43:13-25.

Bradley N. (2007). Marketing Research: tools \& techniques. Oxford : Oxford University Press.

Bulent, M. \& Seigyoung, A. (2006). Creating a firm level dynamic capability through capitalizing on Market Orientation and Innovativeness. Journal of the Academy of Marketing Science, 34 (1):63-73.

Chakravarthy, B.S. (1986). Measuring strategic performance. Strategic Management Journal, 7:437-458.

Cronje GJ, Du Toit J \& Motlatla M. (2004). Introduction to Business Management. 6th ed. Cape Town: Oxford Business Press.

Deng, S. \& Dart, J. (1994). Measuring market orientation: A multi-item approach. Journal of Marketing Management, 10 (8):725-742.

Deshpandé, R. (1999). 'Foreseeing' marketing. Journal of Marketing, 63: 164-167.

Department of Trade and Industry (DTI). (2005). Integrated strategy on the promotion of entrepreneurship and small business enterprises. http://www.dti.gov.za/smme/strategy.pdf Date of access: 23 Jun 2012.

Dockel, J.A \& Ligthelm, A. A. (2005). Factors responsible for the growth of small businesses. South African Journal of Economic and Management Sciences, 8(1):54-65.

Dobni, C. B. \& Luffman, G. (2000). Implementing marketing strategy through a market orientation. Journal of Marketing Management, 16: 895- 916 .

Edigheji, O.E. (2010). Constructing a democratic developmental State in South Africa: Potentials and Challenges. Cape Town: Human Science Research Council Press.

Ellis, P.D. (2006). Market orientation and performance: A meta-analysis and cross-national comparisons. Journal of Management Studies, $43(5): 1089-1107$.

Gatignon, H. \& Xuereb, J.B. (1997). Strategic orientation of the firm and new product performance. Journal of Marketing Research, 34(1):77-90.

Gounaris, S.P.\& Avlonitis, G.J. (1997). Marketing orientation and company performance. Industrial Marketing Management, 26:385-402.

Hallberg, K. (2000). A market-oriented strategy for small and medium-scale enterprises. Paper 40, International Finance Corporation. Washington, D.C.: World Bank.

Harris, L.C. \& Ogbonna, E. (2001). Strategic human resource management, market orientation, and organisational performance. Journal of Business Research, 51(2):157-66.

Homburg, C. \& Pflesser, C. (2000). A multiple-layer model of market oriented organisational culture: measurement issues and performance outcomes. Journal of Marketing Research 37(4):449-462.

Ishengoma, E.K. \& Kappel, R. (2008). Business constraints and growth potential of micro and small manufacturing enterprises in Uganda. GIGA working papers 78. Hamburg: German Institute of Global and Area Studies.

Jackson MLP. (2004). Entrepreneurial support in South Africa: a case study of a small enterprise support centre in Johannesburg. PhD. Thesis. Birmingham: University of Birmingham.

Jaworski, B.J. \& Kohli, A.K. (2000). Market-driven versus driving markets. Journal of the Academy of Marketing Science, 28 (1):45-54.

Kanuk, L. \& Berenson, C. (1975). Mail surveys and response rates: a literature review. Journal of Marketing Research, (4): 440-53. 
Karungu, P., Nyandoro, T. \& Stettler, M. (2000). Venture capital as a source of economic empowerment in South Africa. Johannesburg: $\mathrm{KNC}$ and Associates.

Kim, W. C. H. \& Mauborgne, R. (2009). How Strategy Shapes Structure. Harvard Business Review, 9:73-80.

Kohn, S \& Husig, S. (2006). Potential benefits, current supply, utilization and barriers to adoption: an exploratory study of German SMEs. Technovation, 26(1):988-998.

Kotler, P. \& Armstrong, G. (2011). Principles of Marketing. 14th edition. Boston: Prentice-Hall.

Kumar, N. (2009). How emerging giants are rewriting the rules of M\&A. Harvard Business Review, 87 (5):115-121.

Kumar, V., Jones, E., Venkatesan, R. \& Leone, R.P. (2011). Is market orientation a source of sustainable competitive advantage or simply the cost of competing? Journal of Marketing, 75 (1):16-30.

Kurokawa, T. Tembo, F. \& Velde, D.W. (2010). Challenges for the 'one village one product' (OVOP) movement in Sub-Saharan Africa: Insights from Malawi, Japan and Thailand Report.London: Overseas Development Institute.

Lamb, C. W., Hair, J. F., McDaniel, C., Boshoff, C. \& Terblanche, N.S. (2010). Marketing - South African 4th edition. Cape Town: Oxford University Press Southern Africa.

Lichtenthal, J. D. \& Wilson, D. T. (1992). Becoming market oriented. Journal of Business Research, 24:191-207.

Lloyd, H.R. 2002. Small and Medium Enterprises (SMEs): instruments of economic growth and development in a South African regional dispensation. Paper read at the annual conference of the European Regional Science Association held in Port Elizabeth on 2-6 August 2002:Port Elizabeth,pp1-25.

Mahadea, D. \& Rawat, T. (2008). Economic growth, income and happiness: an exploratory study. South African Journal of Economics: The Quarterly Journal of the Economic Society of South Africa = Die Suid-Afrikaansetydskrifvir ekonomie: die kwartaalblad van die Ekonomiese Vereniging van Suid-Afrika. 76 (2): 276-290.

Mahemba, C.M. \& De Bruijn, E.J. (2003). Innovation activities by small and medium-sized manufacturing Enterprises in Tanzania. Creativity and Innovation Management, 12(3):162-173.

Malhotra, N. K. (2010). Marketing research: An applied orientation. $6^{\text {th }}$ edition. Eaglewood Cliffs: Prentice- Hall.

Mantle, C., Harrod, J. \& Nel, B. (1992). Profile of small businesses in South Africa and ways of stimulating the sector. Rivonia: BMI.

Narver, J. C. \& Slater, S. F. (1990). The effect of a market orientation on business profitability. Journal of Marketing, 54 (4):20-35.

Osuagwu, L. (2006). Market orientation in Nigerian companies. Journal of Marketing Intelligence \& Planning, 24: 608-631

Pelham, A.M. (2000). Market orientation and other potential influences on performance in small and medium-sized. Journal of Small Business Management, 38(1):45-67.

Perreault, W., Cannon, J. \& Mccarthy, E. (2011). Basic Marketing. 18th edition. Homewoods: McGraw-Hill.

Roomi, M. A., Harrison, P. \& Beaumont-Kerridge, J. (2009). Women-owned small and medium enterprises in England: Analysis of factors influencing the growth process. Journal of Small Business and Enterprise Development, 16(2): 270-288.

Ruekert, R. W. \& Walker, O. C. (1987). Marketing's interaction with other functional units: A conceptual framework and empirical evidence. Journal of Marketing, 51(1): 1-19.

Saayman, A. (1997). Die rol van die entrepreneur in die ekonomie.Pretoria: University of Pretoria.(M-com dissertation).

Shapiro, B. (1988). What the hell is 'market-oriented'? Harvard Business Review, 66(6):119-125.

Storey, D. (1994). Understanding the Small Business Sector. London: Routledge.

Subrahmanya, M.H.B., Mathirajan, M. \& Krishnaswamy, K.N. (2010). Importance of technological innovation for SME Growth: Evidence from India. World Economic and Financial Surveys, World Economic Outlook (WEO).

Subramanian, M. J. \& Gopalakrishna, R. P. (2001). The Market Orientation- Performance Relationship in the Context of a Developing Economy. Journal of Business Research, 53(1):13-18.

Singh, R. (2009). Does your library have a marketing culture? Implications for service providers.Library Management, 30(3)117-137.

Sinkula, J., Baker, W. \&Noordewier, T. (1997). A framework for market-based organisational learning: Linking values, knowledge, and behaviour. Journal of the Academy of Marketing Science. 25(1):305-18.

Stansfield M \& Grant K. (2003). An investigation into issues influencing the use of the Internet and electronic commerce among smallmedium sized enterprises. Journal of Electronic Commerce Research, 4(1):15-33.

Tambunan, T.T.H. (2011). The impact of the 2008-2009 global economic crises on a developing country's economy: Studies from Indonesia (March 18, 2011). Journal of Business and Economics, 2(3):175-197.

Tsukahara, O. (2006). SMEs financing in Japan (presentation). Tokyo. Japan Finance Corporation for SMEs (JASME).

Uzoka, F.M.E., Shemi A.P. \& Seleka G.G. (2007). Behavioural influences of E-Commerce adoption in a developing country context. Electronic Journal of Information Systems in Developing Countries, 31(4):1-15.

Verhees,F.J.H.M. \& Meulenberg, M.T.G. (2004). Market orientation, innovativeness, product innovation, and performance in small firms. Journal of Small Business Management, 42(2):134-54.

Vieira V.A. (2010). Antecedents and consequences of market orientation: a Brazilian meta-analysis and an international mega-analysis. Brazilian Administration Review, Curitiba, 7:44-58.

Vosloo, W.B. (1994). Entrepreneurship and economic growth. Pretoria: HSRC publishers.

Walsh, F.M. \& Lipinski, J. (2009). The role of the marketing function in small and medium sized enterprises. Journal of Small Business and Enterprise Development. 16: 569-585.

Zebal, M.A. \& Goodwin, D.R. (2012). Market orientation and performance in private universities. Marketing Intelligence and Planning, 30(3): 339-357.

Zikmund, W.G. (2000). Exploring Market Research. $7^{\text {th }}$ edition. Orlando: The Dryden Press Publishers. 
